\title{
Machine Learning-Structural Equation Modeling Algorithm: The Moderating role of Loyalty on Customer Retention towards Online Shopping
}

\author{
Dr.A.M.Mahaboob Basha ${ }^{1}$, Dr.M.Rajaiah ${ }^{2}$, Dr.P.Penchalaiah ${ }^{3}$, Dr.CH.Raja Kamal ${ }^{4}$, B.Niranjana Rao ${ }^{5}$ \\ ${ }^{1}$ Department of Management Studies, Audisankara College of Engineering \& Technology, Gudur, \\ drbasha3@gmail.com \\ ${ }^{2}$ Department of Mathematics, Audisankara College of Engineering \& Technology, Gudur, \\ rajagopal1402@gmail.com \\ ${ }^{3}$ Department of Computer Science, Narayana Engineering College, Gudur, India, \\ padugupati.penchalaiah@necg.ac.in \\ ${ }^{4}$ Department of Management Studies, Kristu Jayanti College, Bangalore, rajkamalmba2006@gmail.com \\ ${ }^{5}$ Department of Mathematics, Vikrama Simhapuri University, Nellore, India, \\ niranjannarmada2211@gmail.com
}

\begin{abstract}
The purpose of the empirical research study was to know the effect of customer satisfaction and customer loyalty on customer retention of digital customer satisfaction. To analyze the data, the structural equation modeling using AMOS was adopted. To understand the concept of customer retention, researcher used the concept of moderator. Used closed ended questionnaire to collect the opinion from various respondents. A pilot survey has ended with the help of 50 samples from various online customers. The total 500 plus samples were taken to conduct the research study. The data validity has done through crone Bach's alpha reliability test (>.70) and factors validity done through CFA followed by model validity has done through goodness of fit index (GFI $>90, \quad$ AGFI $>.90, \quad$ TLI $>.90, \quad$ RMSEA<.08). Applied Hierarchical regression analysis and CFA. The outcome of the research reveals that, there are certain factors like: Ease of Use, Service Quality, Reliability and security are certainly associated with the customer satisfaction which leads to customer retention in online bank transactions. The moderate variable customer loyalty moderates the relationship between customer satisfactions with respect to high customer retention. Taken age, gender, educational qualifications, and income of the customers as control variables. The main variables include: Ease of Use, Service Quality, Reliability and security. The interaction variable is customer loyalty. The study strengthens with various western and Indian reviews, which impact on reliability and validity of the outcome. The practical implications of the study can be generalized under any circumstances. The model will create new insight to the readers as how customer loyalty and customer satisfaction will influence on customer retention.
\end{abstract}

Key words : customer loyalty, customer satisfaction, Ease of Use, Service Quality, Reliability, Security, Mediation, Moderation, etc.,

\section{INTRODUCTION}

In India, after demonetization of currency the need arises for online transactions. The digital transaction $\mathrm{s}$ are having certain advantages as well as disadvantages. The present study is all about, how customers are reacting will go for online/digital purchase. There are numerous factors which will impact on online shopping. They are Ease of Use, Service Quality, reliability and security will play a substantial role. The ease of Use explains about, how conveniently customers are feeling while going for digital/online shopping and service quality; how customers are reacting pre and post digital transactions. Apart from this the reliability and security plays a substantial role, where customers can transfer the fund or do the online transactions with confidently. In online shopping customers will come across, various issues related to purchase and fund transfer, it the responsibility of the retailer to look over the issues of digital customer aspects. In this regard researcher is going to explore various issues and philosophies in literature and even in analysis also.

\section{REVIEW OF LITERATURE}

Identified a model Technology Acceptance Model (TAM), which has shown the significant effect on the customer intention to purchase the product through online[1].The research witnessed that; not only the online products but also, we can purchase certain services from online shopping like: insurance and licenses. All sorts of payments can be done through online transactions [2].Conducted a research opined that the website quality/visualization is essential which helps to attract the customers to main in long run. The frequent purchase or sales will happen through the visualization and appearance of website only [3].witnessed that, the website functionality content understanding which mentioned in the 
website will plays a crucial role. If customers can understand the things well while they go for online shopping, they will go for repeated purchase with the same retailer [4].Customer satisfaction is essential to generate revenue to the manufacturer and retailer. Customer dissatisfaction leads to loss of customer loyalty which leads to discontinuity of customer from repeat purchase and transactions from online or direct [5].Customer satisfaction is a customer expectations fulfillment. The gap has to be fulfilled between customer expectations and actual performance [6].The sophisticated technology and internet facility along with e-commerce/online business resulted in proliferation of digital shopping practices. This provides many opportunities to the business people to expand their business and freedom of choice to the customers to select the products and services which leads to high customer satisfaction [7]. Another study has found website design, merchandise attributes, security, reliability, privacy, payment, delivery; customer service plays significant forecasters of virtual customer satisfaction which leads to customer retention and loyalty in the competitive world[8].For instance, study has conducted and revealed that, the website design plays a crucial and most powerful independent variable for high customer satisfaction, which leads to customer loyalty in the contemporary business world[9].Customer satisfaction can be identified by persons feeling of pleasure or disappointment which will happen due to the comparison between expected and actual performance [10].In general, if the product/service reaches to the expected level of customer than customer will be satisfied otherwise, will leads to customer dissatisfaction. If the customer is highly satisfied will maintain a continuous relationship with the company for a long period which is advantage to the manufacturer, retailer and customer time [11].The genuine product information quality also plays a substantial role while going for online customer satisfaction. The available product information in online should be more accurate which increases customer loyalty in online customer satisfaction [12].The study witnessed that the product information which is available in online and related details which is available in website plays a substantial role for high customer satisfaction[13]. Witnessed that, there are many factors which influence on online customer satisfaction like: content, website design, security and reliability are the major influencing aspects of online customer satisfaction [14].The interface of perceived quality, security, reliability, content, website quality are the essential factors of online customer satisfaction, which plays a substantial role while going for online business transactions[15].

\section{DATA ANALYSIS AND INTERPRETATION}

Ease of Use: In the contemporary world, all most all companies are entering into E-Commerce, Telemarketing and performing E-Banking transactions. The Ease of use, of banking transaction is essential for continuously relying with a customer. Customers need to understand the content available in the website, should feel easy to understand and perform the things through online. Based on the evidences the following hypothesis was developed.

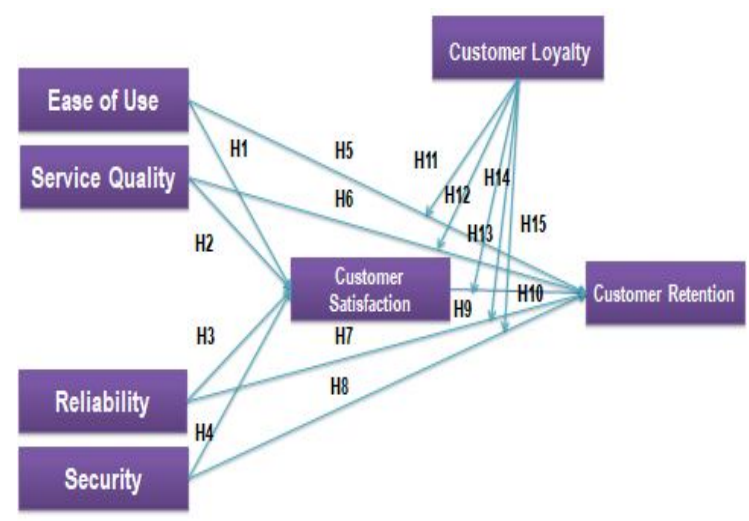

Figure 1: Conceptual Model: Marketing Practices

The above Figure 1 is a conceptual model fit, which explains the concept of how customer satisfaction and customer loyalty will impact on customer retention. H1: There is a significant positive relationship between EOU with respect to satisfaction.

Ease of Use and Customer Retention: It is evident that, where customer feel easy to perform the things in online which creates customer satisfaction and customer retention. Previous research studies also proved that, customer retention will be enhanced by customer satisfaction. A hypothesis was developed based on the above concept.H2: There is a significant positive relationship between Ease of Use and retention.

Service Quality: Rendering service which performing bank transactions are crucial and essential for maintaining continuous relationship with the bank. As earlier studies are also proved that, if any customer felt difficulty while receiving service from the bankers, surely the loyalty of the customer will decline which leads to poor customer retention. Based on the above evidences, developed a hypothesisH2: There is a significant positive relationship between satisfaction and service quality.

Service Quality and Customer retention: Service Quality represents, the quality which we are providing while rendering services to the customers. Service quality will enhance the customer satisfaction leads to customer retention. Especially in banking sector, the service quality plays a pivotal role while performing online banking transactions. A hypothesis was developed which resembles, the relationship among the service quality and customer retention. H3: There is a significant positive relationship between service quality and retention

Reliability: Reliability defined as the ability to perform the things in an accuracy manner and consistency in the results. The accuracy and consistency in all transactions are essential for high customer satisfaction. There is a research in such a 
manner that, reliability will moderate the relationship between EOU, Content, Service Quality, Security and customer satisfaction. Based on the above evidences, a hypothesis was developed. H4: There is a significant positive relationship between Reliability and satisfaction.

Customer Loyalty as a Moderator: Customer loyalty can be defined as what extent customer devoted to a company's product and what extent he/she has belief about features and quality of the product and how strong their tendency towards a particular band to purchase repeatedly is known as customer loyalty. The customer loyalty interacts with customer satisfaction in such that as customer loyalty increases can see high customer satisfaction which leads to customer retention. As per the research evidences proved that, customer satisfaction and loyalty will creates customer retention which builds long association with the company related products and services.

H6: Loyalty moderates the relationship between satisfactions such that at higher levels of Loyalty with satisfaction creates customer retention.

H7: Loyalty moderates the relationship between Ease of Use such that at higher levels Loyalty with Ease of Use creates customer retention.

H8: Loyalty moderates the relationship between Service Quality such that at higher levels Loyalty with Service Quality creates customer retention.

H9: Loyalty moderates the relationship between Reliability such that at higher levels Loyalty with Reliability creates customer retention.

H10: Loyalty moderates the relationship between Security such that at higher levels of Loyalty with Security creates customer retention.

Correlation matrix:-

From the Table 1 it is evident that, all the variables have shown significant positive relationship among the variables. Reliability and security are positively associated with customer satisfaction and customer retention. As reliability and security increases, customer satisfaction and customer retention also increase.
The following Table 2 shows the confirmatory factor analysis With the variables of reliability, security, ease of use, service quality, customer loyalty, customer retention etc..

The all variables: reliability, security, quality, content, Ease of Use and other factors also, shown the positive relationship with the customer satisfaction and retention. The Reliability factor contains four indicators with 0.858 reliability followed by standardized loadings are satisfied the standard measurement of reliability [16] reliable transactions (0.706)", Timeliness (0.851)", Accuracy (0.871)", Promptness (0.679)". The (AVE) value is 0.610 and discriminant validity measurement is 0.781 . The security factor contains four indicators with 0.813 reliability followed by standardized loadings, security and safety transactions (0.663)", avoid hacking (0.814)", user Rights (0.806)", payments (0.608)". The (AVE) value is 0.530 and discriminant validity measurement is 0.728 .The retention quality factors contains four indicators with 0.974 reliability followed by standardized loadings, consistency in service (0.96)", value (0.971)", Relationship (0.953)", Trust and Relationship (0.916)". The (AVE) value is 0.902 and discriminant validity measurement is 0.950 .The ease of use factor contains four indicators with 0.812 reliability with standardized loadings are complete info (0.752)", website design (0.894)", user friendly (0.756)", easy to access (0.843)". The (AVE) value is 0.542 and discriminant validity measurement is 0.736 .The loyalty factor contains four indicators with 0.842 reliability followed by standardized loadings are meet customer expectations (0.678)", convenience (0.795)", rewards and awards (0.871)", personal relationship (0.68)". The (AVE) value is 0.578 and discriminant validity measurement is 0.760.The service quality factor contains four indicators with 0.905 reliability followed by standardized loadings are cheque book facility (0.789)", quick response (0.893)", transfer of Funds (0.89)", alert to mobile phones (0.793)". The (AVE) value is 0.774 and discriminant validity measurement is 0.879 .

Table 1: Mean-Standard Deviation- Correlations Results

\begin{tabular}{|c|c|c|c|c|c|c|c|c|c|}
\hline & Mean & SD & EOU & $\begin{array}{l}\text { Service } \\
\text { Quality }\end{array}$ & Security & Reliability & Satisfaction & Retention & Loyalty \\
\hline EOU & 3.9350 & .75362 & 1 & & & & & & \\
\hline Service Quality & 3.8120 & .96859 & $.167 * *$ & 1 & & & & & \\
\hline Security & 4.1634 & .83476 & .037 & $.243 * *$ & 1 & & & & \\
\hline Reliability & 4.0105 & .89200 & $.250 * *$ & $.548^{* *}$ & $.229 * *$ & 1 & & & \\
\hline Satisfaction & 4.1968 & .83703 & .023 & $.326^{* *}$ & $.884 * *$ & $.332 * *$ & 1 & & \\
\hline Retention & 3.9684 & .83648 & $.106^{*}$ & $.388 * *$ & $.486^{* *}$ & $.352 * *$ & $.411 * *$ & 1 & \\
\hline Loyalty & 4.0105 & .82856 & $.094 *$ & $.593 * *$ & $.486^{* *}$ & $.536^{* *}$ & $.578 * *$ & $.298 * *$ & 1 \\
\hline
\end{tabular}


A.M.Mahaboob Basha et al., International Journal of Emerging Trends in Engineering Research, 8(5), May 2020, 1578- 1585

Table 2: Results of Confirmatory Factor Analysis and Measurement Properties

\begin{tabular}{|c|c|c|c|c|c|c|}
\hline $\begin{array}{c}\text { Factors of Online } \\
\text { Customer } \\
\text { Satisfaction }\end{array}$ & Alpha & $\begin{array}{c}\text { Standardized } \\
\text { loadings } \\
(\lambda y i)\end{array}$ & $\begin{array}{c}\text { Reliability } \\
\quad(\lambda 2 y i)\end{array}$ & $\begin{array}{c}\text { Variance } \\
(\operatorname{Var}(\varepsilon i))\end{array}$ & $\begin{array}{c}\text { Variance-extracte } \\
\text { d estimate }= \\
\Sigma(\lambda 2 \text { yi }) /((\lambda 2 y i)+ \\
(\operatorname{Var}(\varepsilon i))\end{array}$ & $\begin{array}{c}\text { Discriminant Validity } \\
= \\
\sqrt{\Sigma(22 y i) /(02 \mathrm{y} i)+(\operatorname{Var}[\mathrm{d} i)]}\end{array}$ \\
\hline \multicolumn{7}{|l|}{ Reliability } \\
\hline $\begin{array}{l}\text { Transaction } \\
\text { Time } \\
\text { Accuracy } \\
\text { Promptness }\end{array}$ & 0.858 & $\begin{array}{l}0.706 \\
0.851 \\
0.871 \\
0.679 \\
\end{array}$ & $\begin{array}{l}0.4984 \\
0.7242 \\
0.7586 \\
0.4610 \\
\end{array}$ & $\begin{array}{l}0.501 \\
0.275 \\
0.241 \\
0.539 \\
\end{array}$ & 0.6106 & 0.781 \\
\hline $\begin{array}{l}\text { Security } \\
\text { safety } \\
\text { hacking } \\
\text { user Rights } \\
\text { payments } \\
\end{array}$ & 0.813 & $\begin{array}{l}0.663 \\
0.814 \\
0.806 \\
0.608 \\
\end{array}$ & $\begin{array}{l}0.4396 \\
0.6626 \\
0.6496 \\
0.3697 \\
\end{array}$ & $\begin{array}{l}0.560 \\
0.337 \\
0.350 \\
0.630 \\
\end{array}$ & 0.5304 & 0.728 \\
\hline $\begin{array}{l}\text { Retention } \\
\text { Consistency } \\
\text { in service } \\
\text { value } \\
\text { Relationship } \\
\text { Trust }\end{array}$ & 0.974 & $\begin{array}{l}0.96 \\
0.971 \\
0.953 \\
0.916 \\
\end{array}$ & $\begin{array}{l}0.9216 \\
0.9428 \\
0.9082 \\
0.8391\end{array}$ & $\begin{array}{l}0.078 \\
0.057 \\
0.091 \\
0.160 \\
\end{array}$ & 0.9029 & 0.950 \\
\hline $\begin{array}{l}\text { Ease of Use } \\
\text { Information } \\
\text { Website } \\
\text { Friendly } \\
\text { Access }\end{array}$ & 0.812 & $\begin{array}{l}0.752 \\
0.894 \\
0.756 \\
0.483 \\
\end{array}$ & $\begin{array}{l}0.5655 \\
0.7992 \\
0.5715 \\
0.2333 \\
\end{array}$ & $\begin{array}{l}0.434 \\
0.200 \\
0.428 \\
0.766 \\
\end{array}$ & 0.5424 & 0.736 \\
\hline $\begin{array}{l}\text { Loyalty } \\
\text { Expectations } \\
\text { Convenience } \\
\text { offers } \\
\text { PersoRelati }\end{array}$ & 0.842 & $\begin{array}{l}0.678 \\
0.795 \\
0.871 \\
0.68 \\
\end{array}$ & $\begin{array}{l}0.4597 \\
0.6320 \\
0.7586 \\
0.4624 \\
\end{array}$ & $\begin{array}{l}0.540 \\
0.368 \\
0.241 \\
0.537 \\
\end{array}$ & 0.5782 & 0.760 \\
\hline $\begin{array}{l}\text { Service Quality } \\
\text { carefulness } \\
\text { QuickResp } \\
\text { Transfer } \\
\text { Alert to Mo }\end{array}$ & 0.905 & $\begin{array}{l}0.789 \\
0.893 \\
0.89 \\
0.793\end{array}$ & $\begin{array}{l}0.6225 \\
0.7974 \\
0.7921 \\
0.6288\end{array}$ & $\begin{array}{l}0.377 \\
0.202 \\
0.207 \\
0.371\end{array}$ & 0.2898 & 0.538 \\
\hline
\end{tabular}

The Table 3 shows that, out of 400 sample respondents the majority $63.6 \%$ of the respondents are belongs to $41-45$ age group people followed by $16.7 \%$ of the respondent are belongs to 41-45 age group and hence, it can be conclude that, the majority of the respondents are belongs to 41-45 age group. The majority $90 \%$ of the respondents are belongs to male group. The majority $68 \%$ of the respondents are belongs to undergraduates followed by $11 \%$ of the responds are belongs to post graduates. The majority of the respondents and their income between 30000-40000 age group. The majority of the respondents and their major experience will fall under 21-25 years. Hence, therefore it can be concede that the majority of the respondents are male category and they hold 2-25 years of experience and their income class is belongs to 30000-40000. Further the analysis can be extended through hierarchical regression analysis The Table 4 shows the results of hierarchical regression analysis with control and main variables and their relationship. Further the analysis can be extended through Table 5 which shows the effect of
Interaction variable which proves the significant effect with the main variable and its related effect with interaction variable. In the first step (Model 1) all control variables viz., gender, age, educational qualification, salary and span of service were entered. Among the control variables age $(\beta=$ $.189, \mathrm{p}<.000)$ followed by salary $(\beta=.387, \mathrm{p}<.000)$ and services $(\beta=.200, \mathrm{p}<.000)$ are significant. The remaining Gender, Education qualification are not significant predictors of customer satisfaction. The control variables model was significant $(\mathrm{F}=69.419, \mathrm{p}<.000)$ explaining $38 \%$ variation at customer satisfaction with the effect of control variable. In step 2 (Model 2) we entered the main variables in regression equation. This direct effects model suggests that the regression coefficients of security $(\beta=.113, \mathrm{p}<.000)$, reliability $(\beta=.205, \mathrm{p}<.000)$ ease of use $(\beta=.270, \mathrm{p}<.000)$, were significant. Explained $15 \%$ extra variance due to main variables. Therefore, in the Table 4 and Table 5 all variables have shown the significant positive relationship with the interaction variable. 
A.M.Mahaboob Basha et al., International Journal of Emerging Trends in Engineering Research, 8(5), May 2020, 1578- 1585

Table 3: Demographic Profile of respondents

\begin{tabular}{|c|c|c|c|}
\hline $\begin{array}{c}\text { Demographic } \\
\text { Characteristic } \\
s\end{array}$ & Category & Number $(N)$ & $\begin{array}{c}\text { Total } \\
(\%)\end{array}$ \\
\hline \multirow{6}{*}{ Age } & $25-30$ & 12 & 2.1 \\
\hline & $31-35$ & 24 & 4.2 \\
\hline & $36-40$ & 62 & 10.9 \\
\hline & $41-45$ & 362 & 63.6 \\
\hline & $46-50$ & 95 & 16.7 \\
\hline & $>50$ & 14 & 2.5 \\
\hline \multirow{2}{*}{ Gender } & Male & 513 & 90.2 \\
\hline & Female & 56 & 9.8 \\
\hline \multirow{5}{*}{$\begin{array}{l}\text { Educational } \\
\text { Qualification }\end{array}$} & $\mathrm{SSC}$ & 14 & 2.5 \\
\hline & ITI & 16 & 2.8 \\
\hline & Inter & 86 & 15.1 \\
\hline & UG & 389 & 68.4 \\
\hline & PG & 64 & 11.2 \\
\hline \multirow{6}{*}{ Income } & $0-10000$ & 5 & .9 \\
\hline & $10001-20000$ & 42 & 7.4 \\
\hline & 20001-30000 & 109 & 19.2 \\
\hline & $30001-40000$ & 272 & 47.8 \\
\hline & $40001-50000$ & 125 & 22.0 \\
\hline & $>50001$ & 16 & 2.8 \\
\hline \multirow{6}{*}{ Service } & $1-10$ & 18 & 3.2 \\
\hline & $11-15$ & 34 & 6.0 \\
\hline & $16-20$ & 88 & 15.5 \\
\hline & $21-25$ & 332 & 58.3 \\
\hline & $26-30$ & 90 & 15.8 \\
\hline & $>30$ & 7 & 1.2 \\
\hline
\end{tabular}

Data Sources: Field Survey

Table 4: Regression Analysis Properties

\begin{tabular}{|c|c|c|}
\hline \multirow{2}{*}{$\begin{array}{c}\text { Dependent } \\
\text { Variable }\end{array}$} & Satisfaction & Satisfaction \\
\hline & Model 1 & Model 2 \\
\hline $\begin{array}{c}\text { Independent } \\
\text { Variable }\end{array}$ & $\begin{array}{l}\text { Control } \\
\text { Variables }\end{array}$ & Main Variable \\
\hline Gender & $\begin{array}{r}.007 \\
(.193 ; .847)\end{array}$ & $\begin{array}{c}-.035 \\
(-1.055 ; .292)\end{array}$ \\
\hline Age & $\begin{array}{c}.189 * * * \\
(4.667 ; .000)\end{array}$ & $\begin{array}{c}.155^{* * * *} \\
(4.339 ; .000)\end{array}$ \\
\hline Education & -.057 & -.003 \\
\hline Qualification & $(-1.196 ; .232)$ & $(-.063 ; .950)$ \\
\hline Salary & $\begin{array}{c}.387^{* * *} \\
(7.895 ; .000)\end{array}$ & $\begin{array}{c}.250 * * * \\
(5.632 ; .000)\end{array}$ \\
\hline Service & $\begin{array}{c}.200 * * * \\
(3.616 ; .000)\end{array}$ & $\begin{array}{c}.118 * \\
(2.413 ; .016)\end{array}$ \\
\hline Security & & $\begin{array}{c}.113 * * * \\
(3.785 ; .000)\end{array}$ \\
\hline Reliability & & $\begin{array}{c}.205^{* * *} \\
(5.264 ; .000)\end{array}$ \\
\hline Ease of Use & & $.270 * * *$ \\
\hline
\end{tabular}

Service Quality

R2

Adjusted R2

$\Delta \mathrm{R} 2$

F-Value

$\Delta$ F-Value

Df

Regression coefficients are reported

.381

.376

.381

69.419

69.419

(6.679;.000)

$-.034$

$(-1.009 ; .313)$

.530

.523

.149

70.100

44.273

$(9,559)$ parenthesis. ${ }^{* * *} \mathrm{p}<.001 ; * \mathrm{p}<.01 ; * \mathrm{p}<.05$

Table 5: Regression Analysis Properties

\begin{tabular}{|c|c|c|c|}
\hline $\begin{array}{c}\text { Dependent } \\
\text { Variable }\end{array}$ & $\begin{array}{c}\text { Satisfaction } \\
\text { Model } 1\end{array}$ & $\begin{array}{c}\text { Satisfaction } \\
\text { Model } 2\end{array}$ & $\begin{array}{c}\text { Satisfaction } \\
\text { Model } 3\end{array}$ \\
\hline Independent & Control & Main & Interaction \\
\hline Variable & Variables & Variable & Variables \\
\hline Gender & $\begin{array}{c}.074 \\
(1.624 ; .105)\end{array}$ & $\begin{array}{c}.155^{* * * *} \\
(5.140 ; .000)\end{array}$ & $\begin{array}{c}.140 * * * \\
(4.526 ; .000)\end{array}$ \\
\hline Age & $\begin{array}{c}.005 \\
(.098 ; .922)\end{array}$ & $\begin{array}{c}-.074 * \\
(-2.232 ; .026)\end{array}$ & $\begin{array}{c}-.067^{*} \\
(-2.019 ; .044)\end{array}$ \\
\hline $\begin{array}{l}\text { Education } \\
\text { Qualification }\end{array}$ & $\begin{array}{c}-.048 \\
(-.815 ; .415)\end{array}$ & $\begin{array}{c}.058 \\
(1.512 ; .131)\end{array}$ & $\begin{array}{c}.046 \\
(1.214 ; .225)\end{array}$ \\
\hline Salary & $\begin{array}{r}.129 * \\
(2.115 ; .035)\end{array}$ & $\begin{array}{c}.017 \\
(.403 ; .687)\end{array}$ & $\begin{array}{c}.014 \\
(.338 ; .736)\end{array}$ \\
\hline Service & $\begin{array}{c}.087 \\
(1.259 ; .205)\end{array}$ & $\begin{array}{c}-.058 \\
(-1.288 ; .198)\end{array}$ & $\begin{array}{c}-.048 \\
(-1.079 ; .281)\end{array}$ \\
\hline Security & & $\begin{array}{c}-.017 \\
(-.613 ; .540)\end{array}$ & $\begin{array}{c}.118 \\
(1.044 ; .291)\end{array}$ \\
\hline Reliability & & $\begin{array}{c}.030 \\
(.818 ; .414)\end{array}$ & $\begin{array}{c}.077 \\
(.345 ; .730)\end{array}$ \\
\hline Ease of Use & & $\begin{array}{c}.092 * \\
(2.388 ; .017)\end{array}$ & $\begin{array}{c}.578 * * \\
(2.826 ; .005)\end{array}$ \\
\hline $\begin{array}{l}\text { Service } \\
\text { Quality }\end{array}$ & & $\begin{array}{c}.712 * * * \\
(23.185 ; .000)\end{array}$ & $\begin{array}{c}.271 * \\
(2.430 ; .015)\end{array}$ \\
\hline Satisfaction & & $\begin{array}{c}.026 \\
(.663 ; .507)\end{array}$ & $\begin{array}{c}.176 \\
(.908 ; .364)\end{array}$ \\
\hline $\begin{array}{l}\text { Satisfactio } \\
\text { nX Loyalty }\end{array}$ & & & $\begin{array}{c}.289 \\
(1.029 ; .304)\end{array}$ \\
\hline $\begin{array}{l}\text { Reliability } \\
\text { X Loyalty }\end{array}$ & & & $\begin{array}{c}.030 \\
(.186 ; .853)\end{array}$ \\
\hline $\begin{array}{l}\text { Security } \\
\text { X Loyalty }\end{array}$ & & & $\begin{array}{c}.004 \\
(1.208 ; .228)\end{array}$ \\
\hline $\begin{array}{l}\text { ServiceX } \\
\text { Loyalty }\end{array}$ & & & $\begin{array}{c}007^{* *} \\
(4.270 ; .000)\end{array}$ \\
\hline $\begin{array}{ll}\text { Ease } & \text { of } \\
\text { Use } & \mathrm{X}\end{array}$ & & & $\begin{array}{c}.009 * \\
(-2.584 ; .010)\end{array}$ \\
\hline Loyalty & & & \\
\hline $\mathrm{R} 2$ & .048 & .606 & .621 \\
\hline Adjusted R2 & .039 & .599 & .611 \\
\hline$\Delta \mathrm{R} 2$ & .048 & .558 & .015 \\
\hline F-Value & 5.641 & 85.833 & 60.428 \\
\hline$\Delta \mathrm{F}$-Value & 5.641 & 158.151 & 4.395 \\
\hline Df & $(5,563)$ & $(10,558)$ & $(15,553)$ \\
\hline
\end{tabular}






Figure 2: Confirmatory Factor Analysis Model

From the above Figure 2 it is evident that, the sex-factor model fitted the data fine $($ chi-square $=736.991 ; \mathrm{df}=237$ have shown well [18] and the [RMSEA] $=0.061 ; \mathrm{RMR}=0.030$; comparative fit index $[\mathrm{CFI}]=.948 ; \mathrm{TLI}=.940 ; \mathrm{GFI}=.906$, AGFI $=0.881$. The CFI for the six-factor model proves 0.90 and the RMSEA was 0.061. RMSEA of less than 0.08, in general, provides a good fit for the data which includes a model [19]. The comparative fit index (CFI>0.90) gives good fit of the model[20]. This goodness-of statistics for the six-factor model renders evidence of construct distinctiveness for security, reliability, Ease of Use, Service, loyalty and retention. The AGFI was 0.881 , the recommended criteria value is 0.80 [21]. In fact [23] suggested the techniques to conduct the analysis. In this study, the variance-extracted observed for all the variables exceeded the recommended level of 0.50 [22] and also exceeded the squared correlation between the variables.In the first step (model1) all control variables like: age, gender, educational qualification, salary and span of service were entered. Among the control variables gender $(\beta=.074, \mathrm{p}<.105)$ age $(\beta=.005, \mathrm{p}<.922)$ educational qualifications $(\beta=.048, \mathrm{p}<.415)$ followed by salary $(\beta=.129, \mathrm{p}<.035)$ and services $(\beta=.087, \mathrm{p}<.205)$ are not significant predictors of customer satisfaction. The control variables model are not significant $(F=5.641)$ explaining $48 \%$ variation at customer satisfaction with the effect of control variable. In step 2 (Model 2) we entered the main variables in regression equation. This direct effects model suggests that the regression coefficients of service quality $(\beta=.712, p<.000)$, were significant. Explained $17 \%$ extra variance due to main variables

\section{Graph 1: Loyalty $\rightarrow$ retention and Satisfaction}

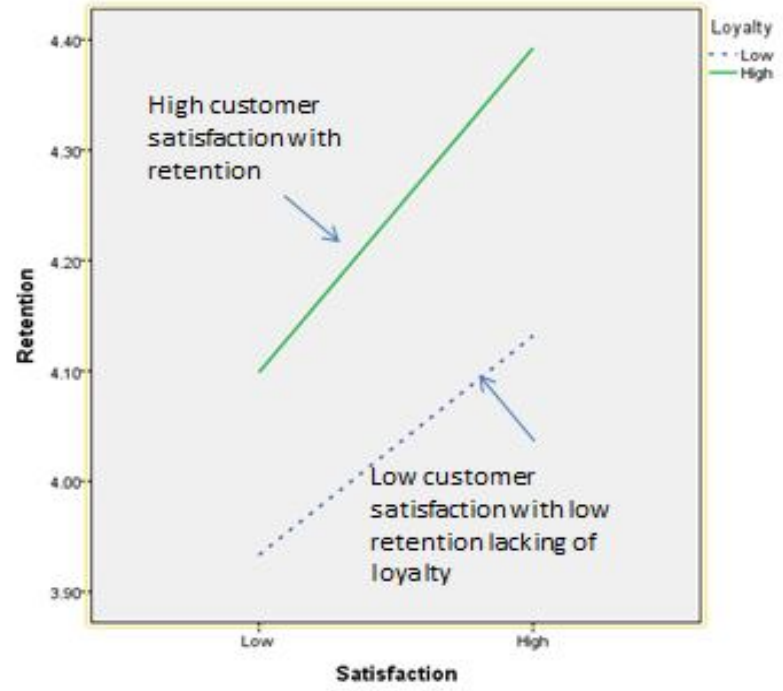

Graph 2: Loyalty $\rightarrow$ retention and Ease of Use

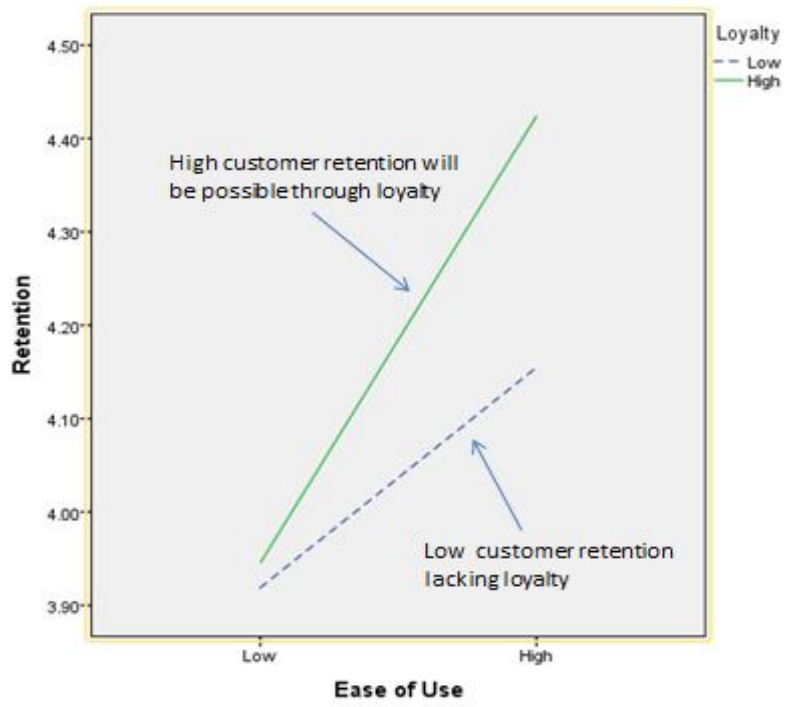

Graph 3: Loyalty $\rightarrow$ retention and Security

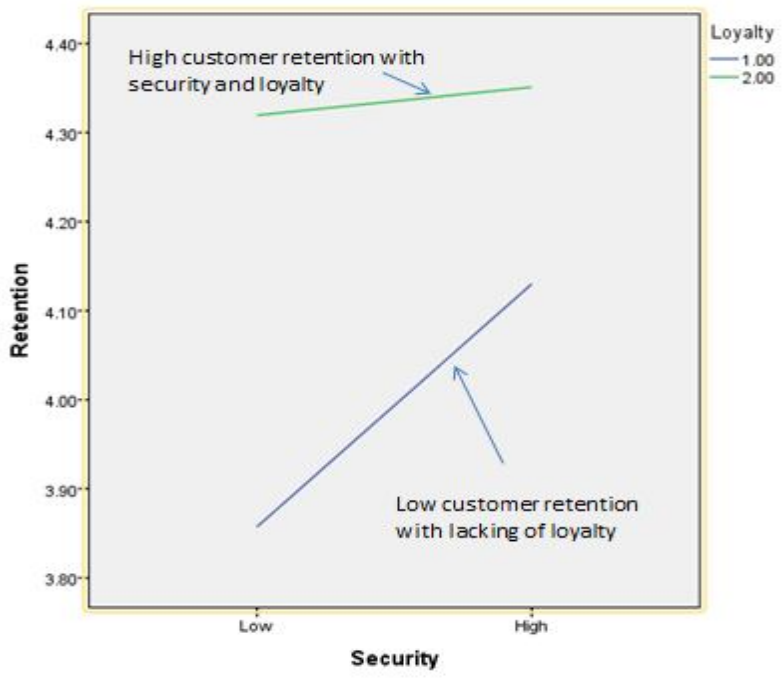


Graph 4: Loyalty $\rightarrow$ Retention and Reliability

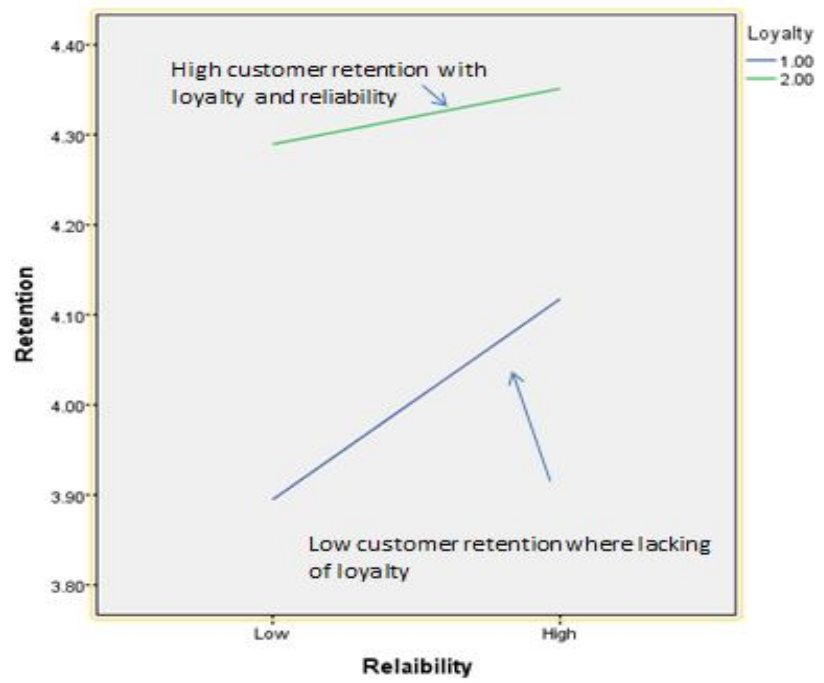

Graph 5: Loyalty $\rightarrow$ Retention and Service Quality



From the above Graph 1 it is evident that, the customer loyalty will moderates the relationship between customer retention and customer satisfaction as customer loyalty increases the along with customer satisfaction also will also increase consequently customer retention also increase. From the above Graph 2 it is evident that, ease of use as customer loyalty increases the along with customer satisfaction also will also increase consequently customer retention also increase. From the above Graph 3 it is evident that, customer retention and security as customer loyalty increases the along with customer satisfaction also will also increase consequently customer retention also increase. From the above Graph 4 and Graph 5 it is evident that, the customer loyalty will moderates the relationship between customer retention and reliability as customer loyalty increases the along with customer satisfaction also will also increase consequently customer retention also increase. In step 3 (Model 3) we entered the interaction variables in regression equation. The model was significant $(F=60.428, p<.000 ; R 2$
$=.621 ; \Delta \mathrm{F}=4.395, \mathrm{p}<.000 ; \Delta \mathrm{R} 2=.015)$ and explained $3 \%$ of variance on customer satisfaction due to interaction variables followed by the total $55 \%$ of cumulative variance due to main variable, which tells that the addition of $17 \%$ of variance generated with the effect of main variables and with the effect of interaction variable the total cumulative variance is $58 \%$ with the only effect of interaction variable $3 \%$ extra variance can be seen in interaction variable. Therefore, the both control and main variables are showing significant impact on customer satisfaction.

\section{FINDINGS}

1. The sex-factor model fitted the data fine (chi-square $=$ 736.991; $\mathrm{df}=237$ have shown well (Hair et al. (2010) and the $[$ RMSEA $]=0.061 ; \mathrm{RMR}=0.030$; comparative fit index $[\mathrm{CFI}]=.948 ; \mathrm{TLI}=.940 ; \mathrm{GFI}=.906, \mathrm{AGFI}=0.881$. The CFI for the six-factor model proves 0.90 and the RMSEA was 0.061 .

2. The interaction plots have shown significant positive relationship with the customer loyalty. Customer satisfaction with loyalty maximizes the customer retention.

3. The interaction plot has shown significant positive relationship with retention with ease of use and customer loyalty will enhance customer retention.

4. The interaction term loyalty have shown $3 \%$ extra variance in the analysis due to interaction effect of customer loyalty.

5. The crone Bach's alpha reliability value which is more than .70 which shows the reliability of the analysis.

6 . The CFA and related loadings have shown and satisfied the author specified criteria which is $>.50$ value, which shows all the values are strongly loaded.

7. All the factors like: ease of use, service, security and reliability have shown positive correlation in the analysis.

8. The moderating term "loyalty" has shown significant positive relationship with ease of use, service, reliability and security. Where "loyalty" plays a substantial role to increase customer retention in the competitive world.

9. In the overall it can be evident that, all the factors like: ease of use, service quality, security and reliability have shown the significant strong positive relationship with the customer loyalty which assists to improve customer retention in long run.

\section{CONCLUSION}

Therefore, it can be conclude that the moderating factor loyalty have shown the significant relationship with the customer satisfaction followed by it has proved that, the customer retention can also be enhanced. The remaining all variables like: ease of use, service quality, security and reliability have shown the significant positive relationship with the customer loyalty. Hence, organizations need to strive for to enhance customer loyalty and customer retention which helps to maintain the customers in long run. It will facilitate to increase profits to the manufacturer, retailer and customer 
also as "the father of nation", said customer is king, need to give utmost respect to the customers.

\section{CONFLICT OF INTEREST}

With the all authors mutual consent sent this paper for publication in the esteemed journal. All the authors are haven mutual agreement regarding content included in the article. Have not received any fund from state and central government to conduct this research.

\section{ACKNOLEDGEMENT}

We respect the suggestions and modifications of the esteemed editorial board members to strengthen the quality of the research work which we have done at present. We would like to thank to all editorial board members, reviewers and higher officials concern to this journal.

\section{REFERENCES}

1. Hans Kristian et.al (2020). Social User Behavior Analysis of Purchasing Decisions in Instagram Online Store. International Journal of Emerging Trends in Engineering Research, 8(2), 598-601.

2. Gunawan Wang et.al (2019). The Use of Internet of Things and Big Data to Improve Customer Data in Insurance Company. International Journal of Emerging Trends in Engineering Research, 7(12), 756-761. https://doi.org/10.30534/ijeter/2019/047122019

3. B. Vishnu Priya1 \& Dr. JKR Sastry (2019). Assessment of Website Quality based on Appearance. . International Journal of Emerging Trends in Engineering Research, 7(10), 360-375.

https://doi.org/10.30534/ijeter/2019/017102019

4. Tandon, U., Kiran, R., \& Sah, A. (2017). Analyzing customer satisfaction: users perspective towards online shopping. Nankai Business Review International, 8(3), 266-288. https://doi.org/10.1108/NBRI-04-2016-0012

5. Moriuchi, E., \& Takahashi, I. (2016). Satisfaction trust and loyalty of repeat online consumer within the Japanese online supermarket trade. Australasian Marketing Journal, 24(2), 146-156. https://doi.org/10.1016/j.ausmj.2016.02.006.

6. Oliver, R. L. (2015). Satisfaction: A Behavioral Perspective on the Consumer. New York, NY: Routledge.

7. Pappas, I. O., Pateli, A. G., Giannakos, M. N., \& Chrissikopoulos, V. (2014). Moderating effects of online shopping experience on customer satisfaction and repurchase intentions. International Journal of Retail and Distribution Management, 42(3), 187-204. https://doi.org/10.1108/IJRDM-03-2012-0034

8. Trong, V. H., Khanh N. T. V., \& Gim, G. (2014). Evaluating factors influencing consumer satisfaction towards online shopping in Viet Nam. Journal of Emerging Trends in Computing and Information Sciences, 5(1), 67-71. https://doi.org/10.5539/ass.v8n13p40

9. Chen, Z., Ling, K. C., Ying, G. X., \& Meng, T. C. (2012). Antecedents of online customer satisfaction in China. International Business Management, 6(2), 168-175. https://doi.org/10.3923/ibm.2012.168.175

10. Kotler, P., \& Keller, K. L. (2012). Marketing Management (15th ed.). New Jersy, Prentice Hall.

11. Williams, P., \& Naumann, E. (2011). Customer satisfaction and business performance: a firm-level analysis. Journal of Services Marketing, 25(1), 20-32. https://doi.org/10.1108/08876041111107032

12. Gelard, P., \& Negahdari, A. (2011). A new framework for customer satisfaction in electronic commerce. Australian Journal of Basic and Applied Sciences, 5(11), 1952-1961.

13. Maditinos, D. I., \& Theodoridis, K. (2010). Satisfaction determinants in the Greek online shopping context. Information Technology and People, 23(4), 312-329. https://doi.org/10.1108/09593841011087789

14. Alam, S. S., \& Yasin, N. M. (2010). An investigation into the antecedents of customer satisfaction of online shopping. Journal of Marketing Development and Competitiveness, 5(1), 71-79.

15. Chang, H. H., \& Chen, S. W. (2009). Consumer perception of interface quality, security, and loyalty in electronic commerce. Information and Management, 46(7), 411-417. https://doi.org/10.1016/j.im.2009.08.002

16. Nunnally J (1978) Psychometric theory. McGraw-Hill, New York

17. Kaiser, H.F. (1974) An index of factorial simplicity. Psychometrics, 39, 31-36.

18. Hair J, Black W, Babin B, Anderson R, Tatham R (2010) .Multivariate data analysis, 7th edn. Pearson Prentice Hall, Upper Saddle River

19. Browne, M.W. and Cudeck, R. (1993). Alternative ways of assessing model fit, in Bollen, K.A. and Long J.S.(Eds), Testing of structural equation models, Sage, Newbury Park, CA, pp.136-162.

20. Jöreskog K, Sörbom D (1993) LISREL 8. Scientific Software International, Chicago.

21. Byrne B (2010) Structural equation modeling with AMOS. Rutledge, Taylor \& Francis Group, New York.

22. Fornell C, Larcker D (1981) Evaluating structural equation models with unobservable variables and measurement error. J Mark Res 18(1):39.

23. Cole, D. A. (1987). Utility of confirmatory factor analysis in test validation research. Journal of counseling and Clinical Psychology, 55, 584. 